\title{
Kultura a tradice: rekapitulace vztahu dvou alternativních pojmů
}

\author{
Vít Erban \\ Katedra filosofie a religionistiky, Teologická fakulta Jihočeské univerzity v Českých Budějovicích, Kněžská 8, České Budějovice
}

Do redakce doručeno 9. března 2020; k publikaci přijato 17. června 2020

\section{CULTURE AND TRADITION: RECAPITULATION OF THE RELATIONSHIP BETWEEN TWO ALTERNATIVE TERMS}

ABSTRACT The article deals with theory of tradition as one of the fundamental theoretical and terminological problems of cultural anthropology which has impact on its methodology, range of resolved themes and the way or the direction of putting questions. It tries through excerption of basic encyclopaedic and dictionary literature, selected writings and authors from the field of anthropology and other related disciplines (mainly sociology and folklore studies) capture, summarize and recapitulate general "story" of the term and the notion of tradition in the course of the last 150 years - from the beginnings of the anthropological thought in the second half of the 19th century through the themes of acculturation, modernization and cultural change in the half of 20th century to the contemporary challenges which the collaboration with the disciplines from the field of natural sciences today brings. The emphasis is put on inherent competition with culture as the fundamental and key concept of cultural anthropology. Both these terms are often considered and used as alternative (equivalent) and therefore we can ask why the anthropology has preferred the term culture to the term tradition (whereas folklore studies did the opposite), how anthropology was explicitly and implicitly considering the term tradition during its development and how the notion of tradition was gradually changing according to actual survey topics and the dialogue with other disciplines. Last but not least we can consider the future of the concept of tradition which is significantly returning today not only in the theoretical and expert level but also as our experienced identity focus in the current changing and interconnecting world.

\section{KEY WORDS history of cultural anthropology; $20^{\text {th }}$ century; culture; tradition; cultural transmission; cultural change}

ABSTRAKT Článek se věnuje teorii tradice jako jednomu z ústředních teoreticko-terminologických problémů kulturní antropologie, který má současně vliv na její metodologii, rejstřík témat, které řeší, ale způsob a směr kladení otázek. Snaží se prostřednictvím excerpce základní encyklopedické a slovníkové literatury, vybraných děl a autorů z oblasti antropologie a jiných př́buzných oborů, se kterými během svého vývoje antropologie vstupovala do dialogu (především sociologie a folkloristiky), postihnout, shrnout a rekapitulovat obecný „př́běh“ pojmu tradice za posledních 150 let - od počátků antropologického myšlení v druhé polovině 19. století přes témata akulturace, modernizace a kulturní změny v polovině 20. století až po současné výzvy, které přináší interdisciplinární spolupráce s obory z oblasti př́rodních věd. Důraz je přitom kladen na přirozenou konkurenci s ústředním pojmem kulturní antropologie, kterým se stala kultura. Oba pojmy se občas považují za v jistém smyslu alternativní (vzájemně zaměnitelné), a proto se nabízejí otázky, proč v antropologické teorii dostal přednost pojem kultura před pojmem tradice, zatímco ve folkloristice došlo k opaku, jak antropologie explicitně i implicitně pojem tradice během svého vývoje chápala a jak se toto pojetí tradice $\mathrm{v}$ antropologickém diskurzu postupně proměňovalo $\mathrm{v}$ závislosti na aktuálních výzkumných tématech a průnicích s jinými vědními obory. V neposlední řadě se lze ptát po budoucnosti tohoto pojmu, který prodělává návrat nejen v rovině odborně-teoretické, ale stává se praktickým, doslova žitým ohniskem identity v současném proměňujícím se a globalizujícím se světě.

KLÍČOVÁ SLOVA dějiny kulturní antropologie; 20. století; kultura; tradice; kulturní transmise; kulturní změna

Může se zdát překvapivé, že kulturní antropologie jako obor zabývající se mimo jiné šírením a předáváním kulturních prvků v čase a prostoru, se po celou dobu své existence téměř zcela obešla bez pojmu tradice. Tento pojem nebyl v kulturní antropologii nikdy natolik klíčový, aby se mu dostalo přes- nějšího teoretického vymezení, natož aby byl často rozvíjen v metodologických diskuzích či testován a aplikován v praxi terénního výzkumu. Svědčí o tom už jen náhled do několika nejužívanějších zahraničních antropologických slovníků či encyklopedií, ve kterých pojem tradice nemá samostatné 
heslo (např. Levinson - Ember, eds. 1996; Barnard - Spencer, eds. 2004; Rapport - Overing 2004) a pokud se alespoň vyskytuje v rejstř́ku, tak jen ve velmi volných souvislostech odkazujících $\mathrm{k}$ jiným tématům, aniž by byl jasně vymezen a definován (např̀. Ingold, ed. 2002; Birx, ed. 2006). Slovníků, které tradici explicitně definují a rekapitulují její pojetí v antropologii, je nápadně méně (např. Winthrop 1991, 300-301; Barfield, ed. 1997, 470-471). Stejně vyznívá i náhled do českých encyklopedických a přehledových prací. Zatímco teorii tradice se běžně a podrobně věnují slovníky sociologické (Geist 1994, 513; Linhart - Vodáková, eds. 1996; Jandourek 2012, 239), etnologické a národopisné (Blahůšek, ed. 2011, 98-99; Brouček - Jeřábek, eds. 2007, 1065), české antropologické práce bud' pojem tradice vůbec nezahrnují (Vodáková - Vodáková - Soukup, eds. 2000; Soukup 2011) nebo jej definují jen stručně (Malina 2011, ed., online).

$\mathrm{V}$ této stati se pokusíme objasnit, proč a jak $\mathrm{k}$ tomu vlastně došlo a také vysledovat, jak se převážně implicitní pojetí tradice $\mathrm{v}$ antropologickém myšlení postupně vyvíjelo. Pozornost zaměříme především na kulturní antropologii, zatímco podněty z oborů, které jsou kulturní antropologii blízké (sociologie, evoluční biologie) či blízce prŕbuzné (etnografie, etnologie, folkloristika), zmíníme jen výběrově a namátkově - především v těch případech, které kulturní antropologii zřetelně ovlivnily nebo ve kterých dochází k explicitnímu dialogu s antropologickým pojmem kultura. Konečně se pokusíme odhadnout, jestli je absence pojmu tradice a jeho odsunutí na okraj zájmu v antropologickém myšlení již víceméně definitivní, nebo se rýsují nové možnosti, v nichž by teorie tradice mohla nabýt většího významu a využití.

\section{TRADICE JAKO „ODPADNÍ PRODUKT“ ANTROPOLOGICKÉ TEORIE KULTURY}

Že se v rámci oboru pojem tradice používá velmi zrrídka a nejde o zavedený či přesněji definovaný termín, má především historické příčiny. Antropologie vznikala v 19. století jako vědní disciplína obracející se do evoluční minulosti lidstva nebo zachycující tehdejší kulturní prvky v jejich domněle původní, autentické podobě nezasažené „civilizací“. Otázka tradice tak nebyla zpočátku přiliš problematizovaná, brala se jako základní či výchozí stav, ve kterém „my“ (jako moderní evropská civilizace) nacházíme „ty druhé“ a pokoušíme se o nich něco dozvědět ještě předtím, než je toto naše vzájemné setkání nevyhnutelně promění, tedy civilizuje a modernizuje. Problém, nakolik „ti druzi“ skutečně reprezentují původní způsob života, spolu s otázkou, jakým zpo̊sobem se různé lidské společnosti vyvíjejí v neustálém kontaktu a prostřednictvím setrvalé výměny zdánlivě původních kulturních prvků, přichází do antropologie teprve v průběhu 20. století.

Druhým důvodem překvapivého nezájmu o tradici je fakt, že jako klíčový termín se už samotných počátcích antropologie uchytil pojem „kultura“ jako označení pro systém sdílených, společensky předávaných vzorců chování, myšlení a vnímání. Antropologické pojetí kultury se stalo široce a ne- ustále diskutované, nesčíslněkrát formulované a definované, běžně a často aplikované, a takto proniklo do celé řady jiných vědních oborů (např. Kuper 2000; Horáková 2012), ale i běžného, laického užívání. Pojem tradice byl tak v antropologii převrstven a do jisté míry i nahrazen pojmem kultura, stal se jeho synonymem, pouhou součástí nebo dílčím aspektem. ${ }^{1}$ Který z obou pojmů nakonec dostane $\mathrm{v}$ antropologické terminologii přednost, přitom nebylo ve vývoji antropologie úplně jednoznačné - např. německý filosof Johann Gottfried Herder (1744-1803), jako jeden z nejvýznamnějších předchůdců pozdějšího antropologického myšlení, ještě běžně zaměňoval pojmy „humanita“, „kultura“ a „tradice“ (Kroeber - Kluckhohn 1952, 22), naopak německý kulturní historik Gustav Klemm (1802-1867) už dával důsledně přednost pojmu „kultura" (ibid, 25). Kultura v antropologickém pojetí byla poprvé explicitně definována britským antropologem Edwardem Burnettem Tylorem (1832-1917) jako „komplexní celek, který zahrnuje poznání, víru, umění, právo, morálku, zvyky a všechny ostatní schopnosti a obyčeje, jež si člověk osvojil jako člen společnosti." (Tylor 1871, 1) 2. Tylorovo dílo nejen zásadním způsobem pomohlo ustavit vědní obor antropologie, ale také zajistilo slibnou budoucnost pojmu kultura, který se ve 20. století dočkal desítek, ne-li stovek, dalších různě modifikovaných definic (Kroeber - Kluckhohn 1952). Všechny tyto pozdější definice se však shodují v tom, že kultura je 1) naučená, nikoli vrozená; 2) sdílená či kolektivní, nikoli pouze individuální; 3) předávaná horizontálně i vertikálně, tedy $\mathrm{v}$ rámci jedné generace (ze současníků na současníky) i naprríč generacemi (od předků na potomky). Shrňme tedy, že podrobné rozpracování pojmu kultura jako zcela klíčového a základního konceptu antropologického výzkumu vytlačilo na okraj pozornosti a zájmu potenciálně rivalitní či alternativní pojem tradice, který je od té doby v antropologii pokládán za nedělitelnou a jen těžko odlišitelnou součást kultury, již většinou není tř̌eba přesněji specifikovat. Pojem tradice tak zůstal v konkurenci s pojmem kultura „ležet ladem“.

\section{DYNAMICKÁ KULTURA A STATICKÁ TRADICE}

Zajímavý vhled, jak se antropologická teorie kultury vyvíjela v průběhu první poloviny 20. století, poskytuje proslulá a dodnes vydávaná práce amerických antropologů Alfreda

1 Proto kulturní antropologie během svého vývoje o tradici často hovořila, aniž by ji většinou př́mo jmenovala. Existuje celá řada antropologických koncepcí, př́stupů a poznatků, které se těsně či volněji dotýkají tématu tradice. V první řadě jde o školu konfiguracionismu, např. v oblasti studia stylových vzorců, křivek růstu a módy (Alfred L. Kroeber), ale také o antropologické studium kulturních změn (Melville J. Herskovits, Homer G. Barnett, Julian H. Steward), zvláště pak v souvislosti s teorií akulturace (Robert Redfield, Ralph Linton, Melville J. Herskovits) a kulturního ohniska (Melville J. Herskovits). Podrobněji viz např. Sidky 2004; Soukup 2004; Amit 2004; Soukup 2018.

2 V této proslulé definici nicméně Tylor ještě chápe kulturu jako ekvivalent pojmu „civilizace“. 
L. Kroebera a Clyde Kluckhohna (1952) 3 . V pečlivě komentovaném soupisu nejrůznějších definic kultury, utříděných do několika základních kategorií a podkategorií, je patrné, že přestože v antropologii termín „kultura“ víceméně vytlačil nebo alespoň trvale potlačil termín „tradice“, paradoxně právě tímto pojmem si řada autorů ve své snaze charakterizovat a definovat kulturu pomáhala ${ }^{4}$. Tyto zmínky o tradici v definicích věnovaných primárně kultuře ukazují, jak byl v tomto období, jako určitý vedlejší výsledek přemýšlení o kultuře, $\mathrm{v}$ antropologii a př́buzných disciplínách pojem „tradice“ intuitivně či implicitně chápán. Tak např́klad ty definice kultury, které Kroeber s Kluckhohnem označili jako „Historické“, mají v tomto soupise jedinou podkategorii nazvanou „Důraz na společenské dědictví neboli tradici“. Ta kromě několika dalších definic opírajících se o pojem tradice obsahuje např. definici antropologa Roberta Lowieho charakterizující kulturu jako „celek společenské tradice“ nebo vymezení antropologa Alfreda R. Radcliffe-Browna, který kulturu považuje za „proces kulturní tradice (...), kterým jsou v dané sociální skupině nebo tř́dè dále predávány (...) jazyk, víra, představy, estetické soudy, znalosti, dovednosti a zvyklosti všeho druhu z osoby na osobu nebo z jedné generace na dalši “ (ibid, 47, 48). Kroeber $\mathrm{s}$ Kluckhohnem $\mathrm{v}$ komentáři $\mathrm{k}$ takto zaměřeným definicím připouštějí, že pojem tradice nemusí označovat jen hotový, výsledný produkt, ale i dynamický proces tvorby, obecně však těmto typům definic kriticky vytýkají, že jsou ve své většině prríliš statické, protože staví člověka do pasivní role nositele tradic a zanedbávají jeho aktivní vklad, tvorbu a účast na své kultuře (ibid, 48-49). Z kontextu této podkategorie je totiž patrné, že různí autoři se k pojmu „tradice“ uchylovali nejčastěji právě tehdy, když chtěli zdůraznit ty části nebo aspekty kultury, které se předávají jako víceméně neměnné, hotové a definitivní. Naopak ve skupině definic, kterou Kroeber s Kluckhohnem označují jako „Genetické“ s podkategorií „Důraz na kulturu jako produkt či artefakt" (ibid, 64-65), která aktivní vklad člověka zohledňuje a považuje jej za klíčový, se termín „tradice“ příznačně vůbec nevyskytuje. Také závěrečné shrnutí volných výroků o kultuře obsahuje výňatek textu, v němž antropolog Leslie A. White pokládá tradici za způsob předávání kultury, která má však oproti tradici zřetelně dynamický aspekt: „Tradice - nebiologický přenos vzorcu chování z jedné generace na dalši“. K tomu však dodává, že „kultura je kumulativní stejně jako kontinuální; díky objevưm a vynálezům jsou pridávány nové prvky. Také je progresivní v tom, že čas od času dosahuje efektivnějších prostředků prizpiosobeni se přírodnímu prostředí nebo kontroly nad ním" (ibid, 100). Mưžeme tedy shrnout, že antropologické myšlení první poloviny 20. století většinou považovalo tradici za statickou, setrvačnou složku

3 V citacích $\mathrm{z}$ tohoto díla nevycházíme z českého překladu (Kroeber - Kluckhohn 1969/1970), ale prrekládáme je př́mo z originálu. Totéž platí pro všechna další citovaná díla.

4 Kroeber s Kluckhohnem v tomto souboru definic z období od Edwarda B. Tylora do roku 1950 napočítali celkem 23 definic kultury, ve kterých je zdůrazněn či zmíněn vliv tradice a společenského dědictví (Kroeber - Kluckhohn 1952, 150). kultury. Tradice se pouze pasivně předává, zatímco kultura, jako mnohem komplexnější a dynamičtější atribut lidské existence, se neustále mění a přetváří. Lze tedy upřesnit, že rozvoj antropologické teorie kultury pojem tradice neodstranil, ale významně zjednodušil, zúžil a omezil jeho význam.

\section{TRADICE VE VÍRU MODERNIZACE A KULTURNÍCH ZMĚN}

Sémantické ochuzení pojmu tradice vedlo k tomu, že v antropologii se tento pojem začal používat spíše v metaforicky volném, přibližném a intuitivním významu. Hovoří se např. o jednotlivých „tradicích“ (ve smyslu subkulturní rozmanitosti v rámci určité kultury) nebo o „tradicionalismu“ (jako snaze o nastolení „původni“ kulturní autenticity). Tradice se stává součástí ustálených slovních spojení, jako je např. „ústní tradice“, „tradiční kultura“ (v protikladu vůči moderní společnosti) nebo „tradiční (tj. předkolumbovská či předkoloniální) minulost“ (Shanklin 1981, 71). Dokonce ani časté spojení „kulturní tradice“ se nevnímá jako redundantní (Ben-Amos 1984, 120). Tyto pojmy a dichotomie jsou sice v dnešní antropologii kritizovány jako nepřesné a zavádějící, přesto se staly součástí běžného terminologického úzu a pronikly nejen do jiných oborů, ale i do laického užívání.

Podněty pro přesnější používání pojmu tradice v antropologii přinesla novější výzkumná témata poloviny 20. století, jako je akulturace, kulturní změna a technologicko-ekonomický, politický a sociální rozvoj třetího světa. V tomto kontextu se pojem tradice používal k označení konzervativních a statických tendencí, které kultuře brání adekvátně reagovat na změnu přírodních, ekonomických, politických a kulturně-historických podmínek a zamezují tak jejímu rozvoji a začlenění do globálních procesů modernizace.

$\mathrm{V}$ této souvislosti se pojem tradice významně prosadil zejména $\mathrm{v}$ díle amerického antropologa Roberta Redfielda, který jako nástroj svého studia rolnických komunit ve vztahu $\mathrm{k}$ městským centrům formuloval a rozpracoval koncepci tzv. „Velkých a Malých tradic“. Jako „Velkou“ označil Redfield menšinovou tradici městských elit, jež je písemně kodifikovaná a pečlivě, prostřednictvím vzdělanosti, kultivovaná a rozvíjená, zatímco „Malá“ je většinová tradice venkovských rolníků, jež se předává výhradně ústně, nesystematicky a je příliš konzervativní na to, aby mohla pružně reagovat na měnící se podmínky a efektivně přijímat nové trendy (Redfield 1953, 1956). „Malá tradice“ je pevným atributem venkovské komunity, která si už jen svou sociální a geografickou uzavřeností, relativní ekonomickou soběstačností a omezenými možnostmi komunikace s vnějším světem udržuje zavedené zvyky a nedůvěru $\mathrm{k}$ inovacím. Veškeré akce $\mathrm{v}$ takové komunitě podle Redfielda nevyplývají ani tak z individuálních rozhodnutí, jako spíše $\mathrm{z}$ přirozeného a odvěkého řádu věcí, a tudíž jsou považovány za nezbytné a jediné možné. Přestože byl tento Redfieldův koncept později (ne zcela oprávněně) kritizován jako výhradně teoretický a postavený spíše na ideálních, etnocentrických konstrukcích převzatých z předchozí litera- 
tury než na výsledcích terénního výzkumu (Shanklin 1981, 73-74), stal se poměrně hojně a úspěšně využívaný v celé řadě konkrétních studií státních společností zahrnujících různé segmenty městského a venkovského obyvatelstva v jejich vzájemném vztahu. Je ovšem pravda, že zejména Robert Redfield vnesl do témat akulturace a kulturní změny velmi konzervativní a dlouhodobě neudržitelné pojetí tradice, které antropoložka Eugenia Shanklin (ibid, 74) později shrnula takto:

1. „Tradice je silou, která brání změně, růstu a kreativitě, tj. slouži jako prostredek uchování;

2. Tradice je iracionální, emotivní reakcí;

3. Tradice zajištuje vnitřní soudržnost;

4. Tradice vymizí nebo bude vymýcena modernitou a racionální volbou jakožto rysů městského prostředí."

Redfield však nebyl jediný, tento náhled na tradici vyplýval z dobového úhlu pohledu na aktuální problematiku modernizace. Velmi podobně, tedy jako jakousi „svěrací kazajku“ pojal tradici např́íklad i izraelský sociolog Shmuel Noah Eisenstadt, když ve své publikaci, zpochybňující zavedené eurocentrické modernizační teorie aplikované na rozvojový svět, napsal: „Tradici si lze snad nejlépe představit jako rutinizovanou symbolizaci modelu společenského rádu (...); také ji můžeme nahližet jako zpusob ohodnocení, stejně jako schválení a legitimizace, totality' kulturního a společenského řádu či jakékoli jeho části“"(Eisenstadt 1973, 139).

\section{TRADICE SE OTEVÍRÁ BUDOUCNOSTI}

V posledních desetiletích 20. století se pojetí tradice jako pasivní a bytostně konzervativní síly zásadně mění. Jedním z prvních podnětů byl článek amerického sociologa a afrikanisty v oblasti etiopských studií Donalda N. Levina (1968), který na základě př́kladů několika nezápadních společností předložil silnou kritiku modernizační teorie a vyvrátil premisu, že tradice a kulturní změna musí být nutně v rozporu. Značný vliv získala ve společenských vědách také publikace amerického sociologa Edwarda Shilse (1981), v níž je rebelie a nedůvěra $\mathrm{k}$ zavedeným hodnotám a postupům jádrem každé tradice - jen díky této vnitřní dynamice může tradice přetrvávat a vyvíjet se tváríi $\mathrm{v}$ tvář měnícím se životním podmínkám. Také v antropologické teorii a výzkumu začíná postupně převládat tendence chápat tradici jako tvưrčí a dynamickou složku kultury, která svým trvalým odkazem k minulosti (at’ už skutečné, imaginární nebo dodatečně vytvořené) a směřováním do předpokládané budoucnosti zároveň citlivě reaguje na přítomné, aktuální potřeby a výzvy. Antropologové si začínají všímat, nakolik je tradice v každé společnosti konstruovaná tak, aby tyto nezbytné procesy kulturních změn odůvodňovala, racionalizovala a posvěcovala. Tradice tak $\mathrm{v}$ antropologii přestává být vnímána jako fixní a statická složka kultury, která se pouze předává, a naopak se stává flexibilním vzorcem porozumění a interpretace, který usnadňuje vstřebávat, začleňovat a využívat nové podněty.
Tradice tedy v procesu kulturních změn umožňuje kultuře zachovávat si, udržovat či vytvářet určitou kontinuitu a zároveň - s pomocí této kontinuity - umožňuje procesy kulturních změn regulovat, směřovat a cílit do budoucnosti. Současně si antropologové všímají, nakolik zejména v případě politických a národnostních rituálů, ale i nejrůznějších kontrakulturních hnutí, vystává potřeba vytvářet a zakládat zcela nové tradice (Hobsbawm - Ranger 1984). Výstižně formulují tento nový, v zásadě paradoxní náhled na tradici američtí antropologové Richard Handler a Jocelyn Linnekin: „Jedním $z$ největších paradoxů ideologie tradice je to, že pokusy o kulturní ochranu nevyhnutelnè mění, rekonstruují nebo vynalézají právě ty tradice, které chtěji upevnit. Tradice nejsou ani pravé ani falešné, protože pokud pravá tradice odkazuje k nedotčenému a nezměnitelnému dědictví minulosti, pak jsou všechny pravé tradice falešné. Ale pokud (...) je tradice vždy definována prítomností, pak jsou všechny takovéto falešné tradice opravdové. Pravé a falešné - pojmy, které byly používány k odlišení objektivní reality od habadiury - jsou nevhodné, pokud jsou aplikovány na společenské jevy, které nikdy neexistuji stranou našich interpretaci" (Handler - Linnekin 1984, 288).

Americká antropoložka Eugenia Shanklin (1981) podrobně formulovala výzkumný program tohoto obratu v chápání tradice. Rozlišila 1) pasivní, analytické pojetí tradice převzaté z teoretické literatury sociálních věd (především É. Durkheima, M. Webera, K. Marxe a F. Tönniese), postavené na eurocentrických a etnocentrických základech a 2) pojetí aktivní, praktické a domorodé, zaznamenané v etnografické literatuře. Obě tato pojetí existovala podle ní v antropologii po celá desetiletí, avšak pasivní, analytické pojetí bránilo dlouhou dobu antropologům plně si uvědomit a docenit, jak jinak může tradice fungovat v odlišných kulturních a sociálních kontextech. Shanklin dokládá, že i tak významní antropologové, jako byl Robert Redfield, Claude Lévi-Strauss nebo Ernst Gellner, ač byli sami terénními výzkumníky, stále zůstávali v zajetí pojmových dichotomií odvozených z předchozí teoretické literatury. Navrhuje, aby se antropologie definitivně osvobodila od autority analytického pojetí sociálních věd a soustředila se více na výsledky vlastních terénních výzkumů, ze kterých často vyplývá, nakolik tradice hraje ve svém odkazu na minulost velmi aktivní, dynamickou a flexibilní roli v utváření současnosti a směřování do budoucnosti. „Pojem tradice, podobně jako kultura, je použiván tak často a v tolika kontextech, že (...) možná už ani nemá žádný smysl. Zatímco nevidim žádný důvod, proč se pokoušet prijít s jediným významem tohoto pojmu, věrím, že je mnoho diovodù, proč zkoumat jeho důsledky, spís než jej použivat jako obecně známý, samozřejmý pojem obklopený mlhavými, ideálními předpoklady“. (ibid, 86) Vytyčuje přitom dva možné úhly pohledu či směry výzkumu -1) je třeba studovat tradici v jejím „hodnotícím užití a 2) v jejím „posvěcujícím užití. Obě tato užití či funkce tradice přitom vystupují bud' ve vztahu 1) interním (tedy jak dotyčná společnost odvoláváním se na tradici hodnotí a/nebo posvěcuje to, co se děje v ní samotné) a/nebo 2) vztahu externím (jak dotyčná společnost hodnotí a/nebo posvěcuje to, co nastává v jejím vztahu k vnějšímu prostředí). „Implicitní v rámci obou 
těchto směrů je předpoklad, že tradice má uchovávající funkci pouze vzhledem $k$ několika málo vybraným rysům, nikoli $k$ souhrnu veškerého chování. Tyto rysy nejenže nemusejí být ,staré, ale dokonce ani pưvodní." (ibid, 77) Můžeme tedy shrnout, že tradice se v antropologickém myšlení poslední třetiny 20. století „rozpohybovala“ a otevřela změnám poté, co se výrazně zrelativizoval její původní význam.

\section{TRADICE A KULTURA JAKO KOMPLEMENTÁRNÍ POJMY}

V rámci oborů blízkých kulturní antropologii také v oblasti folklorních studií dochází v závěru 20. století ke snahám o rozvoj a rehabilitaci pojmu tradice, a to nikoli v opozici vůči pojmu kultura, ale v jejich úzké souvislosti (např. Ben-Amos 1984; Glassie 1995). Fokloristika pokládá tradici za svůj klíčový termín a rozvíjí jej i v jeho reflektované nejednoznačnosti a rozmanitosti volných významů, vrstev a asociací. „Důležitějši (...) než vztyčovat a pilovat novou definici, která by jen držela a stála jako sousoši (...), je rozvíjet a chápat pojem tradice $v$ šíri jeho sémantického rozsahu. Pokud se význam tohoto pojmu rozevře tak, aby zahrnoval všechny možné zpiosoby, jakými lidé přvédèjí staré na nové, tradice se rozprostře do asociacís hraničními, souvisejícími, rovněž nezbytnými pojmy." (Glassie 1995, 395). Jedním z takových přidružených termínů je podle Henryho Glassie i „kultura“. Tento americký folklorista konstatuje, že antropologická teorie kultury se v kritické reakci na svůj prvotní evolucionismus až př́liš důsledně zbavila historické perspektivy. Potřeba zapracovat historii se však později vrátila s tématy akulturace a kulturní změny. Henry Glassie $\mathrm{v}$ prrímém protikladu vůči pojetí, jež se utvořilo $\mathrm{v}$ antropologii v první polovině 20. století, chápe tradici jako „kulturní $d y$ namiku, jako proces, kterým kultura existuje“ a nabízí ji jako prostředníka tohoto nezbytného propojení mezi kulturou a historií. Kromě toho věŕí, že pojem tradice - přesněji řečeno různých tradic $\mathrm{v}$ rámci jedné kultury - nám může pomoci lépe chápat vnitřní dynamiku, kterou je každá kultura trvale utvářená (ibid, 399). Též izraelský folklorista Dan Ben-Amos spatřuje v dialogu pojmů tradice a kultura jisté výhody a možnosti. Např́klad v př́ípadě studia lidové kultury v městském prostředí lze vhodně rozlišovat mezi tradicemi různých vesnických a etnických skupin, které toto prostředí postupně zabydlují, v jejich vztahu k dominantní městské kultuře. „Takové zaměření pozornosti na sociální základy folklóru (...) si vyžaduje pojetí tradice jakožto kultury.(...) Tímto př́stupem se tradice ve folklóru, podobně jako kultura $v$ antropologii, stává aspektem sociálního vymezení a identifikace." (Ben-Amos 1984, 120) Vidíme, že ve folkloristice se těsná blízkost kultury a tradice nejeví jako nadbytečná, matoucí a zavádějící překážka, ale jako přednost, která umožňuje oba pojmy rozvíjet a aplikovat ve vzájemných aspektech a vazbách.

Spíše však než k pokusům používat oba pojmy v jejich zaměnitelnosti dochází ke snaze vnímat je ve vzájemné komplementaritě. Od konce 20. století se pojem tradice $v$ antropologii (a podobně i v sociologii, etnologii, etnografii a folkloristice) nepovažuje za termín odborný, analytický, který by mohl být - pokud by byl přesněji definován - vhodnou metodologickou pomůckou výzkumu, ale spíše za pojem lidový, nativní či domorodý, který př́íslušníci různých kultur či subkultur chápou a používají různě, $\mathrm{k}$ různým účelům a různými způsoby - nejčastěji však k označení toho, co se jim jeví být 1) časté, obvyklé a ustálené, 2) autentické, původní nebo naopak novodobé, 3) kontinuální a relativně nepřetržité, 4) hodnotné, vzácné a zasluhující péči či ochranu, 5) žádoucí a přikázané v imperativním a normativním smyslu (Blahůšek, et al. 2011, 99). Takto zpravidla vymezují tradici i ty nemnohé antropologické slovníky, které nepřecházejí pojem tradice mlčením. $\mathrm{V}$ nich se tradice vymezuje např. jako „explicitní forma kultury predávaná v čase, jejiž uchovávání je samo o sobě hodnotou“, případně jako „kontinuita porozumění vztahující se $k$ nějaké aktivitě, zpưsobu života nebo projevu, jež vede $k$ určitým činům a přesvědčením" (Winthrop 1991, 300). Neboli ve vymezení pojmu tradice je vždy výslovně zdůrazňována hodnota, která nemusí mít platnost obecnou, ale dodatečně připsanou: „Tradice označující zděděný soubor rysů je kategorií, kterou jednotlivci a společnosti připisují projevüm, přesvědčením a způsobưm chování $v$ prítomnosti s cílem dodat jim hodnotu pro budoucnost. (...) Poskytuje dưvody pro uchování, pro zvláštní zacházení, pro péči (...) Tradice je tak územím imaginace, ale její prítomnost má velmi významné di̊sledky pro sociální život." (Barfield, ed. 1997, 470). Vidíme, že na přelomu století se tradice stala pojmem, který antropologové používají nikoli tehdy, když hovoří o „těch druhých“, ale tehdy, když reflektují, jak „tito druzi“ hovoří sami o sobě. V jisté nadsázce lze tedy říct, že „tradice“ je v tomto pojetí vlastně vnitřní, domorodé označení toho, co antropologové zvnějšku studují a popisují jako „kulturu“.

\section{NÁVRAT TRADICE V MEZIOBOROVÝCH SOUVISLOSTECH}

Současně se však rýsují i nové perspektivy studia tradice. $\mathrm{Na}$ počátku 21. století dochází k častému propojování poznatků a metod kulturní antropologie s evoluční biologií a tím i k výraznému rozvoji studia kulturní evoluce (např. Cronk 1999; Soukup 2011; Richerson - Boyd 2012; Ovčáčková, ed. 2017). Tyto přístupy částečně navazují na neoevolucionismus poslední třetiny 20. století, především na směry evoluční psychologie, sociobiologie a memetiky, které byly antropology ve své době přijímány spíše kriticky nebo nedůvěřivě, v současné době však rozvíjejí nové metody mnohdy postavené na počítačově programované matematické simulaci. $Z$ takových současných směrů získala značný ohlas například teorie podvojné dědičnosti, která zdo̊razňuje, že lidská kultura vznikala na základě evolučních principů, ale současně její vznik měl a doposud má silný zpětný dopad na průběh a směřování biologické evoluce. Geny a kulturní prvky spolu interagují, a proto je třeba biologickou a kulturní evoluci nahlížet a studovat ve vzájemných zpětných vazbách (Richerson - Boyd 2012). Protože právě v takové vzájemné vazbě biologie a kul- 
tury vznikají kulturní tradice, k objasnění jejich vzniku, rozvoji a šíření je nejen možné, ale i nutné využít principy známé z biologické evoluce. Pro interdisciplinární studium tradic je zvlášt podnětná kulturní fylogenetika, která prozkoumává zjevné i méně nápadné paralely mezi biologickou a kulturní evolucí a s pomocí fylogenetických metod se pokouší objasnit vznik, rozvoj a širrení vybraných kulturních prvků (typicky např. artefaktů, jazyků či pohádkových motivů) nebo i celých kultur (Mace, et al. 2016, Lipo, et al. 2017, Ovčáčková, ed. 2017, 230-279). K tomu má co říci také kognitivní antropologie, která dokládá, že o úspěchu šíření určitých tradic nemusí vždy nutně rozhodovat lidská schopnost jejich nápodoby, uchování a reprodukce - už jen proto, že kulturní transmise bývá zpravidla výběrová, částečná nebo nepřesná. Tradice se šírí spíše na základě kognitivní atraktivity a specifických preferenčních principů, které jsou nevědomé a nezáměrné. Teprve na jejich základě lze vysvětlit, proč se některé tradice šírí úspěšněji než jiné, případně i jejich šíření předpovídat (Morin 2016).

Jedním z velmi důležitých výsledků těchto mezioborových průniků, který těsně souvisí s teorií tradice, je stále diskutovaný předpoklad, že pro vznik kultury je nezbytná kumulativní kulturní evoluce, která hromadí výdobytky ze současníků na současníky a z generace na generaci, a tak postupně nabývá na komplexitě. Tento jev je typický pro člověka, zatímco $\mathrm{v}$ přírodě ho prozatím nacházíme ojediněle jen u některých živočišných druhů, a to ve spíše rudimentární formě. Pro nastartování kumulativní kulturní evoluce je zřejmě nezbytné učení prostřednictvím přesné imitace. Bez možnosti přesné imitace by musel každý jedinec, bez ohledu na svou vynalézavost, schopnost učení a dosaženou úroveň svých předchůdců začínat vždy znovu a od začátku, zatímco přesná nápodoba nám dává možnost investovat více energie a pozornosti do postupných vylepšení, jež se sčítají a mohou tak vytvořit velmi komplexní tradici. Lidé jsou pro přesnou imitaci, jak se jeví i z laboratorních experimentů, zřejmě geneticky predisponováni, zatímco u jiných živočišných druhů probíhá učení na základě jiných principů, jež ke kumulativní kulturní evoluci a tedy ani vzniku komplexních tradic pravděpodobně vést nemohou. (Richerson - Boyd 2005, 155-166; Ovčáčková, ed. 2017, 190-197, 284-291). Specificky lidské tradice založené na výběru, improvizaci a neustálém zdokonalování tedy vznikají díky prvotní schopnosti přesné nápodoby, od které se můžeme následně odpoutat a naučené dále rozvíjet.

Jak je patrné, přírodní vědy mohou dodat studiu tradice další témata, nastolit dosud nepoložené otázky a obohatit metodologii o nové, aktuální postupy, přičemž kulturní antropologie je velmi plodnou oblastí pro taková mezioborová setkání. Nelze přehlédnout, že ve všech těchto směrech ovlivněných evoluční biologií se pojem tradice začíná používat $\mathrm{v}$ exaktnějším významu, než tomu bylo ve společenských vědách minulého století. To může znamenat, že právě dochází $\mathrm{k}$ určité obnově a rehabilitaci tradice jako analytického, odborného termínu. Pojem tradice se tak díky současným interdisciplinárním průnikům možná opět stává plnohodnotným terminologickým nástrojem studia a výzkumu.

\section{LITERATURA}

Amit, Vered, ed. (2004): Biographical Dictionary of Social and Cultural Anthropology. London: Routledge.

Barfield, Thomas, ed. (1997): The Dictionary of Anthropology. Malden: Blackwell Publishing.

Barnard, Alan - Spencer, Jonathan, eds. (2004): Encyclopedia of Social and Cultural Anthropology. London: Routledge.

Ben-Amos, Dan (1984): The Seven Strands of Tradition. Varieties in its Meaning in American Folklore Studies. Journal of Folklore Research, 21(2/3), 97-131.

Birx, H. James, ed. (2006): Encyclopedia of Anthropology. Thousand Oaks: Sage Publications.

Blahůšek, Jan, et al. (2011): Malý etnologický slovník. Strážnice: Národní ústav lidové kultury.

Brouček, Stanislav - Jeřábek, Richard. eds. (2007): Lidová kultura. Národopisná encyklopedie Čech, Moravy a Slezska. Věcná část O-Z. Praha: Mladá fronta.

Cronk, Lee (1999): That Complex Whole. Culture And The Evolution Of Human Behavior. Boulder: Westview Press.

Eisenstadt, Shmuel Noah (1973): Tradition, Change, and Modernity. New York: Wiley.

Geist, Bohumil (1994): Sociologický slovník. Praha: Victoria Publishing.

Glassie, Henry (1995): Tradition. The Journal of American Folklore, 108(430), 395-412.

Handler, Richard - Linnekin, Jocelyn (1984): Tradition, Genuine or Spurious. The Journal of American Folklore, 97(385), 273-290.

Hobsbawm, Eric - Ranger, Terence. (1984): The Invention of Tradition. New York: Cambridge University Press.

Horáková, Hana (2012): Kultura jako všelék. Kritika soudobých př́stupů. Praha: Sociologické nakladatelství.

Ingold, Tim, ed. (2002): Companion Encyclopedia of Anthropology. London: Routledge.

Jandourek, Jan (2012): Slovník sociologických pojmů. 610 hesel. Praha: Grada, 2012.

Kroeber, Alfred L. - Kluckhohn, Clyde (1952): Culture. A Critical Review of Concepts and Definitions. Cambridge: Peabody Museum of American Archeology and Ethnology.

Kroeber, Alfred L. - Kluckhohn, Clyde (1969/1970): Kritický nástin systémů a definic kultury. 1., 2. svazek. Brno: Krajské osvětové středisko.

Kuper, Adam (2000): Culture. The Anthropologists' Account. Cambridge: Harvard University Press.

Levine, Donald N. (1968): The Flexibility of Traditional Culture. Journal of Social Issues, 24(4), 129-141.

Levinson, David - Ember, Melvin, eds. (1996): Encyclopedia of Cultural Anthropology. New York: Henry Holt.

Linhart, Jiří - Vodáková, Alena, eds. (1996): Velký sociologický slovník. II. P-Ž. Praha: Karolinum.

Lipo, Carl P. - O’Brien, Michael J. - Collard, Mark - Shennan, Stephen J., eds. (2017): Mapping our Ancetors. Phylogenetic Approaches in Anthropology and Prehistory. London and New York: Routledge.

Mace, Ruth - Holden, Clare J. - Shennan, Stephen, eds. (2016): The Evolution of Cultural Diversity. A Phylogenetic Approach. London and New York: Routledge.

Malina, Jaroslav, ed. (2011): Encyklopedie antropologie. Brno: Př́rodovědecká fakulta Masarykovy univerzity. (online). https://is.muni.cz/do/rect/el/ estud/prif/ps11/antropol/web/index.html

Morin, Olivier (2016): How Traditions Live and Die. Foundations of Human Interaction. Cambridge: Oxford University Press.

Ovčáčková, Lenka, ed., et al. (2017): O původu kultury. Biologické, antropologické a historické koncepce kulturní evoluce. Praha: Academia.

Rapport, Nigel - Overing, Joanna (2004): Social and Cultural Anthropology. The Key Concepts. London: Routledge.

Redfield, Robert (1953): The Primitive World and its Transformations. Ithaca: Cornell University Press.

Redfield, Robert (1956): Peasant Society and Culture. An Anthropological Approach to Civilization. Chicago: University of Chicago Press.

Richerson, Peter - Boyd, Robert (2012): V genech není všechno aneb Jak kultura změnila evoluci člověka. Praha: Academia. 
Shanklin, Eugenia (1981): Two Meanings and Uses of Tradition. Journal of Anthropological Research, 37(1), 71-89.

Shils, Edward (1981): Tradition. Chicago: University of Chicago Press.

Sidky, Homayun (2004): Perspectives on Culture. A Critical Introduction to Theory in Cultural Anthropology. New Jersey: Pearson Prentice Hall.

Soukup, Martin (2011): Kultura. Biokulturologická perspektiva. Červený Kostelec: Pavel Mervart.

Soukup, Martin (2018): Antropologie. Teorie, koncepty a osobnosti. Červený Kostelec: Pavel Mervart.

Soukup, Václav (2004): Déjiny antropologie. Praha: Karolinum.

Soukup, Václav (2011): Antropologie. Teorie člověka a kultury. Praha: Portál.

Tylor, Edward. B. (1871): Primitive Culture. Researches into the Development of Mythology, Philosophy, Religion, Art, and Custom. London: J. Murray.

Vodáková, Alena - Vodáková, Olga - Soukup, Václav, eds. (2000): Sociální a kulturní antropologie. Praha: Sociologické nakladatelství.

Winthrop, Robert H. (1991): Dictionary of Concepts in Cultural Anthropology. Westport: Greenwood Press.

Text je přeloženou, upravenou a doplněnou verzí kapitoly „Tradition or culture? The concept of tradition in cultural anthropology" z knihy: Jaroslav Vokoun (Hg.): Traditionstheorie im Gespräch der Wissenschaften. Zürich: LIT Verlag, 2019. Autor děkuje nakladatelství LIT za laskavé svolení $\mathrm{k}$ publikaci $\mathrm{v}$ češtině.

\section{AUTOR}

Erban, Vít $\left({ }^{\star} 1974\right)$, kulturolog, prozaik a esejista. Vystudoval dramaturgii a scenáristiku na Filmové fakultě AMU a kulturologii na Filozofické fakultě UK v Praze, kde absolvoval též postgraduální studium. Od roku 2003 pracuje jako odborný asistent na Teologické fakultě a Filozofické fakultě JU v Českých Budějovicích. Věnuje se především teorii kultury, symbolické antropologii a vybraným tématům $\mathrm{z}$ antropologie náboženství a antropologie umění. Zvláštní pozornost věnoval tématu masek a maskování (knižně Maska a tvár̆: hra sidentitou $v$ mezikulturních promènách) a vztahu kultury a přírody v díle amerického básníka, esejisty a orientalisty Garyho Snydera. Ve své literární tvorbě tíhne k minimalistickým literárním žánrům a formám na pomezí poezie a prózy (knižně Velký vítr, Hora a obzor). Kontakt: viterban@gmail.com 
